Purpose To quantify the benefits that pharmacists reaped in the day-to-day work in terms of productivity (number of preparations/ day), after the annual upgrade.

Materials and Methods The performance of the APOTECAchemo equipment was analysed before and after the 2012 upgrade. The time required for cyclophosphamide, trastuzumab and gemcitabine reconstitution was also investigated.

Results An average of 45 doses per day was prepared before the upgrade, with a maximum of 60 preparations. After the installation, an average of 75 preparations per day was recorded, with a maximum of 100 . The reconstitution of stable powder drugs (cyclophosphamide, trastuzumab and gemcitabine) during 'spare time' (weekends, early mornings, lunch times) allowed an average gain of 55 (11.5\%), 72 (15\%) and $24(5 \%)$ minutes per day, respectively.

Conclusions The new upgrade allowed us to increase daily productivity by $66.6 \%$. The continuing multidisciplinary dialogue among the stakeholders (physicians, pharmacists, technicians and engineers) enables us to make better use of APOTECAchemo in the daily clinical activity and encourages the technology to develop.

No conflict of interest.

\section{TCH-032 PHARMACY PREPARATION: RETROSPECTIVE ANALYSIS OF MORPHINE BAGS USED FOR THE PREPARATION OF ELASTOMERIC INFUSION PUMPS}

doi:10.1136/ejhpharm-2013-000276.223

S Osella, P De Magistris, M Varesio, MC Verlengo, ML Viterbo, F Molinengo, A Leggieri. San Giovanni Bosco, Hospital Pharmacy, Turin, Italy

Background The Italian Law no. 38 of 15 March 2010, has considerably simplified the prescribing and dispensing of medicinal products for the treatment of pain. The law regulates all matters concerning the medical treatment that the Italian state provides to citizens through the National Health Service.

National networks are also in place for palliative care and the treatment of pain, which provide guidelines for implementing the Hospital Territory Without Pain project.

Purpose To examine whether pharmacy compounding can improve the service offered, optimise the time and resources used for preparation, and whether this will require the allocation of new resources.

Materials and Methods Since the beginning of 2011 the San Giovanni Bosco hospital pharmacy has used morphine bags at levels of $2 \%$ morphine per $100 \mathrm{ml}$ to prepare elastomeric infusion pumps for analgesic treatment in addition to vials used. The aim was to monitor how the consumption of morphine was changing by comparing the quantities consumed in 2010 and 2011. This was done using data from the controlled drugs register.

Results In 2011, the quantity of morphine consumed increased by $4.5 \%$. The amount of morphine waste from broken elastomeric infusion pumps, expired vials and bags, bags left unused due to death of the patient or change of treatment and bags with unused content increased in total by $94 \%$. 35\% of morphine destroyed was deemed outside of its validity period while $62 \%$ of elastomeric infusion pumps were returned to the pharmacy as faulty. Despite the increase in expired morphine and the increase in morphine purchased there has been a reduction in spending of approximately $28 \%$.

Conclusions This analysis allowed us to verify that the use of morphine bags has led to a slight reduction in expenditure. It is also important to emphasise the easier fitting of the infusers by operators which leads to time savings.

No conflict of interest.

\section{TCH-033 PHYSICOCHEMICAL STABILITY OF READY-TO-ADMINISTER} EPINEPHRINE INJECTION SOLUTIONS $20 \mu \mathrm{g} / \mathrm{ml}, 50 \mathrm{ml}$

doi:10.1136/ejhpharm-2013-000276.224

$\underline{\mathrm{RM} H e e b}$, I Kraemer. University Medical Center, Pharmacy Department, Mainz, Germany

Background In the University Medical Center Mainz standard concentrations are defined for medicinal products to be administered by continuous injection with syringe pumps in adult intensive care patients. Patient-individual doses are provided by adjusting the injection rate. Various medicines are aseptically prepared in the pharmacy department as ready-to-use products. Batch preparation of the products and keeping them in stock is only possible if stability of the products is tested using a validated method.

Purpose The purpose of this study was to test the stability of ready-to-administer epinephrine solutions for injection $20 \mu \mathrm{g} / \mathrm{ml}$ in $50 \mathrm{ml}$ plastic syringes.

Materials and Methods Epinephrine bulk solution $20 \mu \mathrm{g} / \mathrm{ml}$ was prepared aseptically by diluting Suprarenin $25 \mathrm{mg} / 25 \mathrm{ml}$ SanofiAventis with $5 \%$ glucose infusion solution in empty infusion bags $(\mathrm{PP} / \mathrm{PE})$. The solution was filled with the NeoCare Compounder into $50 \mathrm{ml} \mathrm{BD}$ Perfusion Syringes, Luer Lock Tip, protected from light. The syringes were stored at $2-8^{\circ} \mathrm{C}$ in the refrigerator. Epinephrine concentration was determined by using a validated HPLC method with UV detection at $280 \mathrm{~nm}$ and an innovative HPLC column Nucleodur which contains sulfonyl groups.

Results The concentration of epinephrine in the $50 \mathrm{ml}$ syringes remained unchanged over a period of 2 months. After 28 days and 2 months of refrigerated storage the concentration amounted to $100.5 \%$ and $100.8 \%$ of the nominal concentration, respectively. Neither adrenochrome (detection wavelength $480 \mathrm{~nm}$ ) nor any other degradation products were detected during the study period. With regard to these results batch production is feasible. Stability over 2 months is assured.

Conclusions Epinephrine solution for injection $20 \mu \mathrm{g} / \mathrm{ml}$, aseptically prepared by diluting the marketed injection concentrate with $5 \%$ glucose infusion solution in $50 \mathrm{ml}$ light-protected plastic syringes, is stable under refrigerated storage conditions for at least 2 months.

No conflict of interest.

\section{TCH-034 RECYCLING DRUGS FOR VIRAL DISEASES IN THE OUTPATIENT AREA}

doi:10.1136/ejhpharm-2013-000276.225

IV Martínez Santana, E Abad Lecha, M Izquierdo Navarro, L de las Heras Gonzalo, B González Cuadrillero. Hospital Clínico Universitario de Valladolid, Farmacia, Valladolid, Spain

Background When drugs are multidose packaged, all units must be dispensed to the same patient. Sometimes, patients don't finish their treatment and return units left to the Pharmacy Department. Units returned must be discarded, so it is a loss to the Pharmacy Department.

Purpose To evaluate how much the Pharmacy Department loses when multidose packaged drugs for viral diseases are returned to the outpatient area.

Materials and Methods A single-centre retrospective observational study was carried out in the outpatient area of the Pharmacy Service of the Hospital Clínico Universtiario de Valladolid over 10 months, between June 2011 and March 2012. The following information was collected in structured tables: name of medicine, number of units returned, price to book value per unit and total value. 